\title{
\begin{tabular}{l|l} 
Mibraries & DSpace@MIT
\end{tabular}
}

\author{
MIT Open Access Articles
}

Valuation of Government Policies and Projects

The MIT Faculty has made this article openly available. Please share how this access benefits you. Your story matters.

Citation: Lucas, Deborah. "Valuation of Government Policies and Projects." Annual Review of Financial Economics 4.1 (2012): 39-58.

As Published: http://www.annualreviews.org/doi/pdf/10.1146/annurev-financial-110311-101829

Publisher: Annual Reviews

Persistent URL: http://hdl.handle.net/1721.1/77231

Version: Author's final manuscript: final author's manuscript post peer review, without publisher's formatting or copy editing

Terms of use: Creative Commons Attribution-Noncommercial-Share Alike 3.0 


\section{Valuation of Government Policies and Projects}

Deborah Lucas

MIT

Prepared for the Annual Review of Financial Economics. 


\section{Introduction}

Governments play a central role in the allocation of capital and risk in the economy. ${ }^{1}$ As well as making real investments in infrastructure, property, plant and equipment, governments engage in a wide range of financial activities: They guarantee or make direct loans for housing, education agriculture, small businesses, energy, and trade; explicitly insure bank deposits, defined benefit pension plans, crops, real property, and implicitly insure too-big-to-fail financial institutions; conduct monetary policy through capital market transactions; provide pension benefits to federal civilian and military employees; promise social security and other contingent social insurance payments; and implicitly or explicitly guarantee the obligations of government sponsored enterprises such as the federal home loan banks and the farm credit system.

How should governments assess the cost of such activities, and how does that compare to the valuation methods they typically use in practice? Those questions are important because accurate valuations are necessary for informed investment decisions, effective management, and meaningful public oversight. This paper presents an interpretive review of the growing literature that aims to provide answers by applying the concepts and tools of modern finance to valuing government policies and projects. It also highlights some important examples of where the financial economics approach leads to significantly different answers than the methods currently used by governments to assess the cost of their activities.

The validity of applying the methods of financial economics to valuing government policies and projects rests on the principle that the government's cost of capital, like that of the private sector, depends primarily on the priced risks associated with the activity being evaluated. From that perspective, taxpayers and other stakeholders are equity holders in government investments and through the tax and transfer system bear the associated market risk. The government diversifies away most of the idiosyncratic risk associated with its activities. Although most economists accept that view, market risk is generally not recognized as representing a cost to the government--either by policymakers or by the government accounting rules that operationalize notions of cost. Section 2 reviews the literature on the theoretical and practical relevance of market prices for government valuation.

It should be emphasized that the direct cost of government activities, which is the focus here, is one of a number of considerations that generally go into a cost-benefit analysis of a project or policy. Determining whether or not it is socially optimal for the government to undertake an activity also involves an assessment of its value to beneficiaries, any associated positive and negative externalities, its effects on the distribution of income and wealth, and other policy goals. However, the importance of additional

\footnotetext{
${ }^{1}$ For an overview of those activities see Moss (2004) and Elliott (2011).
} 
information for project evaluation does not diminish the usefulness of obtaining the most accurate possible estimates of the direct costs of government endeavors.

Adapting traditional financial models to government applications gives rise to interesting conceptual and technical challenges for researchers:

- Governments face different constraints than private firms, and they often engage in activities that do not have a direct private analog. Importantly, because of their ability to levy taxes governments are not bound by a break-even constraint. Hence they can offer subsidies which tend to drive out private provision of similar financial services and products, making it harder to identify comparable market prices to use for valuation.

- The relevant horizon for government policies can be considerably longer than for private institutions. For instance, policymakers are interested in the present values of social insurance obligations and the costs of climate change over periods that span a century or longer.

- Government policies can affect market prices, such as when it provides implicit catastrophic guarantees to financial institutions that lower the cost of corporate debt. Such effects complicate the use of market prices to draw inferences about costs.

Those considerations can make the seemingly straightforward problem of choosing appropriate discount rates more difficult in government contexts. Section 3 reviews the literature on inferring risk-adjusted discount rates for government applications, including valuing government direct loans and loan guarantees; evaluating the size of underfunding of state and local pension plans; calculating the cost of capital for real investment projects; and using the insights of the recent literature on long-run risk to assess the underfunding of the social security system.

Many of the most technically interesting applications of financial economics to government valuation problems have employed a contingent claims or derivative pricing approach, whereby the value of claims can be inferred by finding a set of publicly traded securities that replicate (precisely or approximately) their cash flows. Merton (1977 and 1978) was the first to recognize that many government obligations are contingent claims that can be valued most accurately using such methods, and he applied that insight to derive equations to value deposit insurance. Since that time, researchers have developed derivative pricing models to value a wide variety of government guarantees. Section 4 surveys many of those applications, which include guarantees of deposit insurance; pension and social security benefits; Fannie Mae and Freddie Mac; and agricultural loans, mortgages, and corporate obligations. 
The remainder of the paper is organized as follow: Section 2 reviews the theoretical and practical rationales for using market prices to infer the government's cost of capital. Section 3 surveys the research on risk-adjusting discount rates for a variety of government applications, and contrasts those findings with government practice. Section 4 discusses applications of derivative pricing techniques to valuing a variety of government assets and liabilities. Section 5 concludes with a summary of the main points, a discussion of unresolved issues, and suggestions for future research.

\section{The Government's Cost of Capital}

Is the government's cost of capital (and hence the rates it should use to discount future cash flows) similar to that of private businesses and investors? That question, which was the subject of a lively debate between leading economists in the late 1960s and early 1970s, was more recently revisited in Bazelon \& Smetters (1999) and Lucas \& Phaup (2010). The discussion here draws on Lucas \& Phaup (2010), which reviews the theoretical and practical rationales for using market or fair values to evaluate the budgetary cost of government activities.

The private cost of capital has two main components: the pure time value of money and a risk premium. In principle either component could have a higher or lower cost to the government than to the private sector. However, the debate among economists has generally been about whether the government should assign a lower cost to risk than the private sector (e.g., because it can achieve greater diversification), and whether the government has a lower time value (e.g., because it assigns more value to the welfare of future generations).

\subsection{Implications of the Modigliani Miller Theorem for the Government}

Modigliani \& Miller (1958) show that in the absence of market imperfections, the cost of risk associated with a corporate investment depends only on its own risk characteristics, not on the combination of debt and equity used to finance it. By contrast, a common view among some policy analysts and government officials is that the market risk associated with investments is not costly to the government because the government can borrow at Treasury rates.

Applying the Modigliani-Miller balance sheet perspective to government investments is perhaps the clearest way to see why Treasury rates are not the government's cost of capital: risky investments can never be entirely debt-financed. When the government funds risky investments by selling safe Treasury securities, risk is shifted onto current and future taxpayers and other federal stake holders, who effectively become equity holders in a leveraged risky investment. 
For example, the government could fund an investment in common stock with the sale of Treasury securities of equal market value. On average, the portfolio would earn a "profit" each year equal to the equity risk premium. However from a taxpayer perspective, the profit is offset by the cost of the associated market risk. If the stock market did well, the government would be able to pay back the debt and use the surplus to lower taxes or increase other spending. If the stock market performed poorly, the debt still would have to be repaid, either by raising taxes or cutting other spending. ${ }^{2}$ A taxpayer that made the same investment on his own would view the positive expected return as compensation for risk, not as a profit.

\subsection{The Early Debate}

It seems clear that holding a portfolio of publicly traded stocks funded by issuing Treasury securities is not a money machine for the government. However, a more subtle issue is whether most government investment activities are "spanned" by the investments made by the private sector, or whether government investments primarily serve to make markets more complete. Academic interest in that question peaked in the late 1960s and early 1970s following important advances in general equilibrium theory, particularly the contributions of Arrow and Debreu (1954) and Debreu (1959). Those developments allowed for more general welfare analyses of policy. They also highlighted the benefits of risk-sharing, the aggregate limits on risk-sharing, and the role of market prices in aggregating the risk preferences of society.

Diamond (1967) analyzed the role of government investment in an economy with technology risk and a stock market. He concluded that if markets are sufficiently complete for stock prices to reflect the social cost of risk, then those prices are also relevant to the government in evaluating its investment policy. Hirshleifer (1964 and 1966) reached similar conclusions, and argued forcefully for the use of market prices for valuing government investments.

In Jorgenson et. al. (1964), Samuelson and Vickrey argue that because the government holds a large and diversified portfolio of projects, the marginal return from public investment overall is virtually risk-free, and hence should be evaluated at the risk-free rate rather than the higher market rate demanded by less diversified individuals. In a paper that remains highly influential in the policy community, Arrow \& Lind (1970) formalize that argument. Specifically, they posit an economy with complete contingent claims (i.e., complete insurance markets) and no aggregate uncertainty. They conclude that the social and private discount rate is equated at the risk-free rate. Arrow and Lind acknowledge that their conclusions depend

\footnotetext{
${ }^{2}$ The ability of the government to issue debt to fund deficits does not change that conclusion. Any debt issued to cover an investment shortfall eventually has to be repaid, with accumulated interest, out of future tax revenues. That is, taxpayers effectively incur investment losses as they occur; government borrowing serves to change the timing of when taxes are collected to cover the losses.
} 
on the assumption that government investment entails no aggregate risk, and defend the assumption as plausible because correlated risk is likely to be insignificant for many government investments.

Sandmo (1972) clarifies the relation between those opposing points of view. He notes the difference rests on the assumption about whether or not the returns on public investment projects are correlated with the returns on private projects. Sandmo goes on to suggest that for the modern economies of Europe and the U.S. that Hirshleifer's view is more plausible. He also observes that the contributions of Sharpe (1964), Lintner (1965), and Modigliani \& Miller (1958)--a body of work that underpins modern financial economics--are highly relevant to the debate, but rarely cited in the context of public investment.

As discussed by Sandmo and Dreze (1971) and references therein, the question of whether there is a welldefined social (risk-free) discount rate, and whether it can be inferred from market prices also hinges on whether markets are complete and if not the nature of the incompleteness. When markets are incomplete, using Treasury rates to represent the pure rate of time preference can lead to suboptimal government investment decisions, but it is difficult to quantify the bias. The early literature broadly concluded that in the presence of distorting taxes and various other types of market frictions, there is not a unique rate of time preference appropriate for evaluating all pubic investments.

\subsection{Market Incompleteness: Evidence and Implications}

Finding evidence of a large risk premium associated with idiosyncratic risk would support the ArrowLind story that the government has a significant advantage at risk-bearing because it can spread idiosyncratic risk through the tax system. Many empirical studies have tested whether idiosyncratic risk is priced, using the framework of the Sharpe and Lintner Capital Asset Pricing Model (CAPM) or multifactor models (for example Fama \& French, 1992). Those studies find little evidence in support of that view, although researchers continue to revisit the evidence. It has also been suggested that the "equity premium puzzle"- the difficulty of reconciling the observed return on stocks with simple parameterized aggregate pricing models--implies that markets are placing too high a price on risk. However, the robust predictions of asset pricing theory put very few quantitative restrictions on expected or realized returns, and it is difficult to interpret the observed equity premium as evidence for or against the efficiency of financial markets.

As discussed above, the main difference between views of Arrow and Lind and early proponents of using market prices rests on whether or not the returns on public investments are correlated with those on private investments. It appears that most of the government's financial activities in recent decades 
(making or guaranteeing loans, insuring deposits and retirement benefits, and explicitly or implicitly providing insurance to financial institutions), have analogs in the private sector.

It is sometimes asserted (particularly in the context of pension obligations) that because the government can "wait out" market risk but individuals cannot, it is legitimate for the government to treat the risk premium as a gain. However, having a long investment horizon does not avoid the cost of market risk: Bodie (1995) shows that the price of insuring an equity portfolio against a return that is below the riskfree rate actually increases with investment horizon, even if one assumes that stock returns are meanreverting in the long run.

Although concerns about incomplete markets may cast doubts about the use of market prices in some instances, it is not clear there is a generally better alternative for evaluating project costs. The most common alternatives to market prices, governments' own borrowing rates, also are market prices and hence susceptible to similar criticisms. Furthermore, whether the social cost of capital is higher or lower than what is implied by market prices cannot be answered in general. For example, the market price of risk may understate its social cost when the full risk of an activity is not borne by the private sector. That can occur when the government assumes tail risks that are unlike to materialize but that are highly correlated with market downturns. ${ }^{3}$

It is important to recognize that government investment activities may increase social welfare by helping to complete markets, even if markets are complete enough so that it makes sense to treat the government's cost of capital as being equivalent to that of the private sector. ${ }^{4}$ For example, government credit support may alleviate informational and contractual frictions in credit markets (e.g., Stiglitz \& Weiss, 1981, and Williamson, 1994); public financing of infrastructure projects may improve welfare when it is infeasible for the private sector to collect sufficient revenues from users; and through social insurance programs, the government may be increase welfare by improving risk sharing between generations (e.g., Telmer et. al, 1999).

SIDEBAR: Incentives for Government Decision Making

\footnotetext{
${ }^{3}$ Kelly et. al. (2011) examines that idea empirically using data on options prices.

${ }^{4}$ Consistent with that view, Kaplow (2006) develops a framework that formalizes the idea that efficiency, and how much weight should be placed on different generations, are issues that can be separated. In his analysis, increasing efficiency is to the benefit of all generations, and efficiency is properly assessed using market prices.
} 
An important practical reason to include a market risk premium in calculations of governments' capital costs is to avoid the perverse incentives created for policymakers when it is omitted: ${ }^{5}$

Avoiding budgetary arbitrage. Investments in risky claims look cheap for the government when market risk is neglected, which creates an incentive to overinvest in them. For example, the federal student loan program lends to borrowers on more favorable terms than what would be offered by the most efficient and competitive private financial institution. The federal budget reports an expected profit from those loans.

Putting credit and non-credit assistance on a level playing field. Governments can provide assistance to target groups via credit subsidies or in non-credit forms. Neglecting the cost of market risk lowers the perceived cost of credit assistance relative to that of economically equivalent grant or benefit payments, creating an incentive to over-rely on credit assistance relative to other alternatives.

Making financial transactions at market prices budget-neutral. When market risk is not accounted for, buying financial assets at competitive prices appears to make money for the government, whereas selling them appears to lose money, distorting the incentives faced by government portfolio managers.

\section{Risk-adjusting Discount Rates}

This section highlights four important areas where taking a financial economics approach to deriving riskadjusted discount rates yields additional insights, and produces estimates that differ significantly from those used by policymakers: (1) federally-backed credit programs; (2) real investments such as infrastructure projects; and (3) defined benefit pension and social security liabilities.

\subsection{Federally-backed Credit}

Federally-backed direct loans and loan guarantees outstanding for programs such as student loans, mortgage guarantees, farm credit, and small business loan guarantees stood at $\$ 2.5$ trillion in $2010 .^{6}$ By

\footnotetext{
${ }^{5}$ See CBO (2003) and Lucas \& Phaup (2008) for a more complete discussion of the consequences of the omission of market risk in federal budgetary accounting.

${ }^{6}$ That total omits credit-related federal obligations that are not budgeted for under the Federal Credit Reform Act of 1990 , including the $\$ 5.3$ trillion of mortgages and mortgage-backed securities guaranteed or owned by Fannie Mae and Freddie Mac and the financial assets acquired through the Troubled Asset Relief Program. It also excludes obligations classified as insurance such as the deposit guarantees from the Federal Deposit Insurance Corporation
} 
law, the subsidy costs recorded in the federal budget for such programs are calculated under the rules of the Federal Credit Reform Act of 1990 (FCRA). That law specifies that credit subsidy costs are to be calculated by projecting expected future cash flows to and from the government (e.g., interest payments, principal repayments, fees, and guarantee payments), and discounting them to the year a loan is disbursed at Treasury rates of comparable maturities.

Hence, the rules for calculating federal credit subsidies take into account expected losses from defaults, but not the market risk premium that arises because default rates tend to be higher, and recovery rates lower, when the overall economy is weak. Because of the omission of a market risk-premium, several major federal credit programs appear to make money for the government. In 2010, the federal budget showed savings of about $\$ 14$ billion associated with new loan origination under those programs. The apparent savings disappear, and collectively the programs have a significant cost of approximately $\$ 32$ billion when a charge for market risk is incorporated into subsidy calculations (Lucas, 2011).

Choosing risk-adjusted discount rates to estimate the market or fair values of government credit programs and guarantees can be complicated because often there are a lack of comparable transactions from which to draw inferences: Government subsidies tend to drive out the private provision of comparable offering, or similar arrangements are not economically feasible for the private sector to offer at any price. In such instances, it is still possible to estimate an applicable risk premium by considering the expected returns on private sector offerings that share key characteristics, and making adjustments for identifiable differences between government and private credit instruments.

Using risk-adjusted discount rates is often the most straightforward way to value direct loans made by the government (i.e., loans originated, financed, and serviced by the government). The same approach also can be applied to the valuation of many loan guarantee programs by recognizing that the value of a loan guarantee can be approximated by taking the difference between the value of a safe loan and the value of a risky loan with the same promised cash flows. Loan guarantees also can be valued as put options using derivative pricing methods (and more complicated guarantees require the use of such methods); examples of guarantees that have been valued as derivatives are covered in section 4 below.

An example of a sizable credit market which is largely governmental, but where comparable private products do exist and can be used to infer risk-adjusted discount rates, is for student loans. Lucas \& Moore (2007) estimate the fair value of government-backed student loans using information on pricing and loan performance for both government and private student loans. Complications in inferring the

and the pension benefit guarantees from the Pension Benefit Guarantee Corporation; and implicit guarantees of government-sponsored enterprises such as the Federal Home Loan Banks and the Farm Credit System. 
associated market risk premium and program cost include: adjusting for the treatment of administrative costs; identifying the component of quoted interest rates that function as fees to cover administrative costs; adjusting for fixed and floating rates components of flows; differences in the borrower populations, particularly differences in expected default and recovery rates; and differences in loan characteristics such as embedded options to prepay or defer payments. Adjusting for such factors, Lucas and Moore inferred a market risk premium of about 2.2 percent over Treasury yields, which reflects the significant risk in making long-maturity unsecured loans to households. The resulting model of the term structure of riskadjusted interest rates, together with a stochastic model of federal student loan cash flows, is used to estimate the fair value of federal student loans that were originated in 2006. Subsidy rates on the loans (the present value of net losses to the government per dollar of loan principal) inclusive of a risk premium were about 20 percentage points higher than subsidy rates computed using Treasury rates for discounting.

A case where directly comparable private credit arrangements are not available is for the loans guaranteed under the Department of Energy's (DOE) Title XVII program, which offers incentives for innovative energy technologies. Even if banks were willing to extend similar loans without a government guarantee, information about private contractual terms is usually confidential. A workaround for valuing government credit to commercial enterprises is to infer a credit rating based on characteristics of the enterprise and the project. Specifically, projected default and recovery rates (which the government has to estimate whether or not it adjusts for risk) can be mapped into a credit rating using historical data. The risk premium associated with the credit rating can then be used to infer risk-adjusted discount rates for loan cash flows (e.g., Hull et. al., 2005). CBO (2011) took that approach to estimating the fair value subsidy rates for government loan guarantees offered by the DOE under Title XVII for the construction of nuclear power plants. $^{7}$ The inclusion of a market risk premium significantly increases the estimated subsidy on those long-lived, fixed rate loans. For example, $\mathrm{CBO}$ estimates that for a nuclear project with a "B" rating from Standard and Poor's and an assumed 55 percent recovery rate, the subsidy rate is 11 percent when Treasury rates are used for discounting, and 27 percent when the discount rates are risk-adjusted.

A number of researchers have sought to measure the value of subsidies conferred to Fannie Mae and Freddie Mac from their government backing. Prior to being taken into federal conservatorship in 2008 that backing was implicit: although investors assumed they would be protected from losses by the government, the securities issued by Fannie Mae and Freddie Mac did not carry a legal guarantee. Nevertheless, the perception of an implicit guarantee allowed Fannie Mae and Freddie Mac to borrow at

\footnotetext{
${ }^{7} \mathrm{CBO}$ is required under FCRA to use Treasury rates for its budgetary estimates of the cost of credit programs. However, it has undertaken a series of studies that provide fair value estimates of subsidies for government credit programs in order to give policymakers more comprehensive information about program cost.
} 
lower interest rates than similarly risky financial institutions. Ambrose \& Warga (2002) estimated a borrowing advantage of between 43 and 47 basis points over A-rated bonds issued by banks. Using a similar spread assumption, CBO (2001) estimated that Fannie Mae and Freddie Mac received federal subsidies of $\$ 45.4$ billion between 1995 and 2000, based on capitalizing the borrowing advantage over the expected life of debt issued over that period. Implicit federal backing also made their guarantees of mortgage-backed securities (MBSs) more valuable; CBO estimated a capitalized subsidy value on their MBS of $\$ 19.5$ billion over the same period.

With the passage of the Housing and Economic Recovery Act of 2008, federal backing of Fannie Mae and Freddie Mac became explicit, and CBO began to include estimates of the fair value subsidies associated with their new mortgage guarantees in its budget baseline (CBO, 2010a). In the years following the financial crisis, it has become more difficult to identify the fair value of government backing by reference to market prices because very few mortgages have been privately insured. However, some jumbo mortgages continue to be offered by private entities. The subsidy value can be estimated by attributing a portion of the observed spread between jumbo and conforming mortgages (those eligible for purchase by Fannie Mae and Freddie Mac) to the value of the guarantees, and capitalizing that spread over the expected life of mortgages originated in a given year. CBO (2010b) highlights the quantitative significance of risk-adjustment in evaluating those subsidies: Over a 10-year period starting in 2011, fair value subsidies to Fannie Mae and Freddie Mac are projected to total \$53 billion on a fair value basis; using instead Treasury rates for discounting, Fannie Mae and Freddie Mac have a negative subsidy ratethey appear to earn $\$ 44$ billion for the government.

\subsection{Real Investments}

Federal, state and local governments make a variety of real investments that include infrastructure (highways, mass transit, aviation, water treatment and flood control); structures (schools, office space, and military housing); and military equipment. Two federal enterprises, the Tennessee Valley Authority (TVA) and the Bonneville Power Administration (BPA), build and manage the electrical generation and transmission capacity that serves large regions of the Southeast and Pacific Northwest.

As discussed in Section 2.1, the logic of the Modigliani Miller theorem implies that the government's cost of capital should include a risk premium related to the market risk associated with such investments; governments can only borrow at low interest rates because the debt is secured by tax revenues. That observation is particularly important for projects that are justified on the basis that user fees will cover costs. For example, electrical rates charged by TVA and BPA include expected debt servicing costs, but 
not the risk to taxpayers that because of lower-than-expected demand there could be a revenue shortfall that would be borne by taxpayers. ${ }^{8}$

In general, public entities do not recognize a cost of taxpayer equity in assessing their capital costs. At the federal level, the Office of Management and Budget (OMB) is responsible for providing guidance to other federal agencies on the discount rates to be used for cost-benefit analyses. In its published procedures, it explains that discounting is necessary to account for the time value of money, but it makes no mention of adjusting for risk. ${ }^{9}$ Accordingly, OMB specifies the use of Treasury note or bond rates for discounting nominal cash flows; for discounting real cash flows it publishes a schedule of real rates based on Treasury rates adjusted for projections of expected inflation.

State and local governments, and other government entities, also generally take their cost of capital to be the average interest rate on their debt. Those rates may be lower or higher than Treasury rates depending on whether the value of any tax exemptions exceeds the costs of higher default risk and lower liquidity. In any case, because no cost is recognized for taxpayer equity, the cost of capital used in project evaluation is significantly lower than what it would be for a private enterprise evaluating the same project.

As far as I know, comprehensive estimates have not been published on how much capital costs for real government investments are understated, nor have researchers evaluated how much that downward bias has affected the government's investment decisions.

\subsection{Defined Benefit Pension Plans and Social Security}

Governments promise pension benefits to their employees and social security benefits to retired workers and their dependents. Policymakers rely on actuaries' present value calculations to assess whether income from dedicated investment portfolios and projected tax revenues will be sufficient to cover the promised benefits, and if not how large the adjustments to the system need to be to restore balance. Because of the long time horizons involved, the conclusions are highly sensitive to the rates used to discount projected benefits and tax revenues.

The principle of matching discount rates to the risk of the cash flows being discounted also applies to retirement-related cash flows. If accrued public pension benefits are as safe and certain as the other debt obligations of a government, then they should be discounted at a similar rate (with adjustments to undo the effect of tax exemptions). Similarly, pension fund assets should be valued at market prices, which reflect the higher discount rates that investors assign to riskier investments.

\footnotetext{
${ }^{8}$ See Pope (2008) for an account of how BPA managed nuclear power plant cost overruns.

${ }^{9}$ OMB Circular A-94, http://www.whitehouse.gov/omb/circulars_a094\#8
} 
That principle is violated by the guidelines issued by the Government Accounting Standards Board (GASB) for accounting for state and local defined benefit pension plans. GASB allows projected pension benefits to be discounted at the expected rate of return on pension fund assets, even though the assets are composed primarily of stocks and other securities that are considerably riskier than the pension liabilities. Using the rate of return on risky assets to discount safe cash flows understates their value, and therefore understates the funding shortfalls of public sector pension plans. Novy-Marx \& Rauh (2011) estimate the amount by which pension underfunding is understated redoing the present value calculations using a taxadjusted muni rate (representing the value of taxpayer liabilities). Their calculations using tax-adjusted muni rates show that in 2008 , economic underfunding was about $\$ 300$ billion more than official estimates reported. ${ }^{10}$

Rather than being fixed dollar annuities, defined benefit pension promises to current workers are generally subject to market risk. The reason is that even when there is no risk of default by a plan sponsor, the formula that determines the benefit amount is linked to future wage realizations. Future wages are correlated with future stock market outcomes, and that correlation tends to increase with the time horizon (Lucas \& Zeldes, 2006, and Benzoni et. al., 2007). Hence some measures of defined benefit pension benefits are exposed to market risk particularly in the long-run, and the discount rates applied to them need to be adjusted accordingly.

Taking into account long-run risk and its effect on discount rates is particularly important for evaluating the solvency of the social security system. Social security benefits are tied by formula to aggregate wage growth over an individual's working life, and taxes collected each year are proportional to aggregate wages. Different discount rates apply to different cohorts: the benefits eventually received by young workers are subject to decades of aggregate wage risk, whereas the benefits received by retirees are no longer exposed to wage risk. Taking into account the age structure of the population and the time variation in the correlation between wage growth and asset returns, Geanakoplos and Zeldes (2010 and 2011) show that the present value of projected benefits is significantly lower when discount rates are riskadjusted than they are under an actuarial approach that uses Treasury interest rates for discounting. For example, the present value of benefits for a "closed group" (which includes the lifetime taxes and benefits of all people currently in the labor force) is estimated to have a market value of $\$ 19.5$ trillion as compared to a much higher actuarial value of $\$ 30$ trillion. However, risk adjustment also lowers the present value of social security tax revenues relative to their actuarial value. The net effect of adjusting for market risk is

\footnotetext{
${ }^{10}$ They also report estimates using Treasury rates to discount liabilities, but because pension liabilities are not as safe or liquid as Treasury securities that calculation overstates the liability to taxpayers and the value to beneficiaries.
} 
to lower the present value of projected revenue shortfalls for the closed group: the market value of the shortfall is estimated to be $\$ 8.1$ trillion, whereas the actuarial value is $\$ 13.7$ trillion. Although including a risk premium reduces the present value of both social security taxes and benefits, because the taxes are collected before benefits are received, the effect of compounding the risk premium reduces the relative cost of benefits. ${ }^{11}$

\section{Applications of Derivative Pricing Techniques}

Many of the government's financial commitments are contingent claims - derivatives whose value can be inferred from the observed prices and volatilities of privately issued claims using derivative pricing techniques (making appropriate adjustments for the distinct characteristics of government activities). That insight has been applied to variety of applications which are briefly surveyed here.

\subsection{Loan Guarantees and Deposit Insurance}

A comparison across two firms with identical assets - but one with a government debt guarantee and one without a guarantee--serves to illustrate how a government guarantee of a firm's debt affects the value of its debt and equity, and also to identify the value of the debt guarantee. For a firm with guaranteed debt, equity value has two components: The first, analogous to the equity of a levered firm without a guarantee, is a call option on the operating assets of the firm; if the asset value is higher than the face value of the debt at maturity, equity holders receive the difference. The second component is the net value of the guarantee itself, which is the present value of the uncertain stream of savings from being able to borrow at the risk-free rate rather than at a rate that includes a risk premium, net of the value of any fees charged. The Appendix provides an algebraic example that formalizes those conclusions, and which shows that the guarantee can be valued as a put option.

Merton (1977) first demonstrates the correspondence between loan guarantees and common stock put options, and uses that identification to derive a formula to value loan guarantees as put options. Merton (1978) adapts the analysis to deposit insurance by incorporating the effect of costly audits that occur at random intervals over an indefinite period of time. Those analyses build on Merton (1974), which

\footnotetext{
11 In a related analysis, Blocker et. al. (2008) concludes that risk-adjustment makes unfunded social security liabilities larger rather than smaller. Their analysis does not consider the correlation between wage growth and financial market returns. Instead they focus on the value of inflation protection provided to retirees, and use the spread between nominal Treasury securities and TIPs to estimate the value of that inflation protection, which by that measure appears to be very valuable.
} 
provides a pricing formula for risky corporate debt based on the insight that the debt can be viewed as a portfolio consisting of risk-free debt and a short put option on the assets of the firm. ${ }^{12}$

Marcus \& Shaked (1984) estimate the fair value of FDIC insurance using the Merton (1977) model calibrated with data on 40 publicly traded banks and bank holding companies. They conclude (in contrast to several early studies) that the fair value of FDIC insurance is considerably lower than the premiums charged. They also emphasize that the large differences in estimated guarantee values across banks implies that cross-subsidies could be reduced by greater risk-adjustment of premiums by the FDIC.

In that analysis, Marcus and Shaked encounter two practical challenges that often arise when valuing government guarantees to firms using an options pricing approach. The first is how to impute the volatility of a guaranteed firm's asset value. Whereas data on equity values and volatilities are generally available for publicly-traded firms, the market value of debt is rarely reported and hence asset value cannot be directly measured. To solve that problem they rely on an implicit function derived in Merton (1974) that relates the volatility of assets to the volatility of equity. That formula, together with an identity that equates the sum of a firm's debt and equity to the value of firm assets (inclusive of the guarantee value), can be solved numerically to approximate the value of a firm's assets and their volatility.

The second difficulty is that data on the value and volatility of equity is not available for privately-held firms. To estimate the value of guarantees in such cases, the choices are either to assume that privatelyheld firms are analogous to similar publicly-traded firms, or to use a combination of data from public and private firms to infer values for the key input parameters in the pricing model. Falkenheim \& Pennacchi (2003) take the latter approach to valuing private banks' deposit insurance; they predict the risk characteristics of private depository institutions based on supervisory accounting data.

The studies discussed thus far take firm leverage ratios and asset volatilities as exogenous processes. Both, however, are influenced by the behavior of firms and regulators, which in turn is influenced by the presence of guarantees. Pennacchi (1987) reexamines the value of deposit insurance taking into account the response of regulators. Specifically, he considers the effect on the value of the guarantee if at the time of an audit the regulator can force a bank to restore capital to at least its regulatory minimum. The wave of savings and loan bankruptcies during the mid-1980s increased the attention paid to the incentives for risk-taking by guaranteed institutions. Keeley (1990) presents evidence that bank risk-taking, and hence

\footnotetext{
${ }^{12}$ Sosin (1990) uses those techniques to analyze the value of federal loan guarantees to corporations. Specifically, he considers a guarantee on a portion of a hypothetical firm's subordinated debt and its effects on the value of different classes of firm claims. CBO (2004) uses a binomial version of the model to value the federal guarantees made to Chrysler in 1980 and to America West Airlines in 2002, and the associated warrants and fees received by the government in exchange.
} 
the value of deposit insurance, is greater when charter value declines. Pennacchi (1996) points out that when deposit insurance premiums are set to be "actuarially fair" that banks have incentives to take on excessive systemic (priced) risk.

\subsection{Pension Benefit and Social Security Guarantees}

Like deposit insurance, retirement benefit guarantees can be valued as put options. The Pension Benefit Guarantee Corporation (PBGC), an independent federal agency, guarantees the obligations of corporate defined benefit pension plans. Those defined benefit pension plans promise retirees a stream of income for life, based on years of service and wages in the last few working years. Corporations are required to hold dedicated portfolios of pension assets to fund their liabilities. However, if plan assets prove to be insufficient because of low returns or insufficient contributions, companies still must make the promised payments as long as they have the means to do so--the PBGC only becomes responsible for a company's pension liabilities when pension assets are insufficient and the company is insolvent. That situation is most likely to occur when the stock market has fallen and corporate default rates are high. Hence PBGC guarantees expose the government to considerable market risk.

Marcus (1987), Pennacchi \& Lewis (1994), and CBO (2005) estimate the value of PBGC insurance, taking into account the dependence of the government's liability on a random termination date for each firm due to bankruptcy, current funding levels, and the stochastic value of plan assets. The CBO model incorporates more programmatic information than those earlier studies, and also takes into account the value of insurance premiums received. CBO reports that the effect of incorporating market risk doubles the net cost to the PBGC from underpriced premiums relative to an actuarial estimate that uses Treasury rates for discounting. CBO also finds that PBGC premiums, which are set by statute, are extremely underpriced; premiums would have to be increased more than six-fold to cover the present value shortfall from projected future claims (existing losses are sunk and not included in that calculation). Similarly to deposit insurance, the underpricing of PBGC guarantees encourages overinvestment in risky assets which could be destabilizing to the financial system (Bodie, 2011).

Governments also may explicitly or implicitly provide minimum return guarantees on defined contribution pension accounts, whose returns depend on investment realizations. Proposals to include such accounts as part of social security, and the expectation that in the event of unexpectedly poor performance the government would offset a portion of losses, has motivated a number of studies on the cost of such guarantees (e.g., Pennacchi 1999, Lachance \& Mitchell 2002, CBO 2006, and Biggs et. al. 2006). Those analyses demonstrate the applicability of derivative pricing methods to valuing minimum return guarantees on defined contribution accounts. Calculations based on specific proposals illustrate the 
high cost of such guarantees, and the sensitivity of cost to program design. Importantly, the analyses highlight the moral hazard that is created when guarantee fees are underpriced or not risk-adjusted: participants have a strong incentive to invest in high-risk assets because they get the upside but not the downside of the risk.

\subsection{Incorporating Capital Structure Dynamics: Fannie Mae and Freddie Mac}

The estimated value of open-ended debt guarantees on highly levered financial institutions — such as deposit insurance and implicit guarantees on the government-sponsored enterprises like Fannie Mae and Freddie Mac-depends critically on assumptions about firm capital structure and how it responds to profitability and other shocks. ${ }^{13}$ In an influential analysis, Leland (1994) solves for the value of corporate debt when firm asset value follows a diffusion process and capital structure is set optimally. Commercial risk assessment tools such as the framework used by Moody's KMV also take into account the joint dynamics of assets and liabilities for evaluating the probability of default.

Using a risk-neutral stochastic simulation approach, Lucas \& McDonald (2006) estimate the value of the implicit government guarantee on the $\$ 1.7$ trillion of debt issued by Fannie Mae and Freddie Mac as of year-end 2004. To capture the idea that managers may gamble for solvency when default appears imminent, asset volatility is assumed to increase discretely when leverage exceeds a threshold. The preferred parameterization yields a guarantee value of less than $\$ 8$ billion over a 10 -year period for the two enterprises. The effect of risk adjustment is significant: the actual 10-year default probability for Fannie Mae is estimated to be 6.4 percent, whereas the corresponding risk-neutral default probability is 15.2 percent. The combined value at risk at the 0.5 percent level over the same period was estimated to be about $\$ 100$ billion (less than the ex post amount of Treasury infusions into the companies after they entered conservatorship in 2008).

Markus and Shaked (1984), Lucas \& McDonald (2006), and other studies that use derivative pricing techniques to value guarantees to corporations tend to produce cost estimates that are lower than analyses (such as those discussed in Section 3.1) based on capitalizing interest rate spreads. Lucas \& McDonald (2010) suggest several possible explanations for that phenomenon: A federal guarantee may be valued by investors not just because of the direct value of protection from default risk, but also because of other benefits such as increased liquidity or exemptions from regulatory restrictions. Spread-based analyses also may not account for the fact that if asset volatility is held constant, firms with higher charter values will optimally default less frequently than those without guarantees that have lower charter value.

${ }^{13}$ Other financial institutions thought to be implicitly guaranteed include too-big-to-fail financial institutions, the Federal Home Loan Banks, and the Farm Credit System. 
The presence of a government guarantee also may affect the asset price dynamics that are used to estimate the guarantee's value, which could lead to incorrect inferences about cost. Lucas \& McDonald (2010) explore that possibility, and conclude that inferences about the volatility of operating assets made on the basis of stock price volatility are basically the same for a firm with or without a guarantee. However, because the firm's assets include the value of the guarantee, inferences about expected recoveries in the event of a default must take into account the drop in value due to the loss of charter value.

\subsection{Other Applications}

The rules for many government programs (such as eligibility criteria, fee schedules and payoff triggers on guarantees) are only reevaluated periodically or may be set by law, and hence may remain in effect for extensive periods. That friction creates optionality that generally increases government costs. For example, the value of assistance fluctuates with economic conditions and program participation increases with its value. Several studies have incorporated additional optionality into estimates of program cost, including Marcus \& Modest (1986), Lucas \& Moore (2009), and CBO (2010b).

Marcus \& Modest (1986) analyze agricultural price supports, whose value depends on future supply and demand conditions in commodity markets. They show that the U.S. agricultural price support system can be interpreted as the provision of a random number of put options to program beneficiaries. Using a derivatives pricing methodology, they derive and calibrate a valuation formula, and find that the support program raises the ex ante value of some crops by as much as 9 percent (at a corresponding cost to the government).

Lucas \& Moore (2009) estimate the cost to the government of the student loan consolidation option. The consolidation option is a "swaption" which allows a borrower to convert a federal student loan that carries a floating rate into a fixed rate loan with the same rate. Using a stochastic risk-neutral model of the yield curve and Monte Carlo simulation, the option value is shown to be sensitive to the level and shape of the yield curve, and to the behavior of borrowers. ${ }^{14}$ Borrower behavior is estimated using historical loan-level administrative data from the Department of Education. For the period 1998 to 2005, the value of the option at the time of loan origination varies between 1.2 percent and 6.4 percent of loan principal, depending on interest rate conditions in the year of loan origination. Although the observed propensity to exercise the option increases with option value, borrowers do not follow an optimal exercise policy.

\footnotetext{
${ }^{14}$ A risk-neutral approach is a technique whereby the physical probability of default is replaced with weights that combine the physical default probability with risk-adjustment. An advantage is that expected cash flows calculated under a risk-neutral measure can be discounted using risk-free rates, which makes estimation using Monte Carlo simulation relatively straightforward.
} 
Basing the cost estimates on a behavioral model rather than assuming a counterfactual but optimal takeup rate roughly halves the estimated cost to the government.

During the peak of the financial crisis in 2008, the Federal Reserve (Fed) instituted several emergency lending programs that provided government subsidies to borrowers in the form of subsidized put options (CBO, 2010b). For example, under its Term Asset-Backed Securities Loan Facility (TALF), the Fed stood ready to make multi-year non-recourse loans to financial institutions that were collateralized by asset-backed securities (ABS) of various types. The Fed was partially protected from losses by a $\$ 20$ billion first-loss guarantee from Treasury under the Troubled Asset Relief Program and by "haircut" provisions. ${ }^{15}$ The Fed initially capped the facility size at $\$ 200$ billion, but later increased the limit to $\$ 1$ trillion. CBO estimated the fair value subsidy provided by the Fed initially to be $\$ 13$ billion. That estimate was constructed using a risk-neutral asset process for each collateral type that was consistent with market yields in the months preceding program inception. CBO then used Monte Carlo simulations of the calibrated asset processes to value the cash flows to and from the Federal Reserve and the Treasury. The analysis took into account the contractual structure, the effect of haircuts, and importantly, the expectation that program take-up rates would increase if market conditions deteriorated.

Congress responded to the financial crisis by instituting the Troubled Asset Relief Program, which provided up to $\$ 700$ billion for purchase of troubled assets by the government. That legislation required the costs to be evaluated using risk-adjusted discount rates, and both $\mathrm{CBO}$ and OMB provided cost estimates on that basis. Veronesi and Zingales (2009), and a study commissioned by the Congressional Oversight Panel, also evaluated the cost of the government's preferred stock purchases and warrants received under that program using a market approach.

As a final example of where a derivatives pricing approach has been applied to a large government program, CBO (2011) estimates fair values for the mortgage guarantees made by the Federal Housing Administration (FHA), and contrasts the results with budgetary estimates of program cost that use Treasury rates for discounting expected losses. Demand for FHA mortgages increased markedly with the withdrawal from the market of subprime lenders following the financial crisis of the late 2000s; since 2009 it has guaranteed more than 17 percent of new and refinanced mortgages. Because comparable price information is not available for new subprime mortgages, CBO uses the quoted rate schedules for private mortgage insurance (PMI) to infer the market price of mortgage default risk. Borrowers taking out mortgages with less than a 20 percent down payment must purchase PMI for the mortgages to be eligible for purchase by Fannie Mae and Freddie Mac, and those insurers are in a first loss position. CBO

\footnotetext{
${ }^{15}$ A "haircut" is the difference between the value of the collateral and the principal lent against it.
} 
estimated that on a fair-value basis, the program would have a cost in 2012 of $\$ 3.5$ billion. By contrast, discounting projected losses at Treasury rates (as required by law) CBO estimated that the budgetary savings would be $\$ 4.4$ billion.

\section{Conclusions}

This article reviews the rationales for using market or fair value prices for valuing government projects and policies, and surveys much of the existing research that applies the concepts and tools of modern finance to that end. The main points are that:

- Cost estimates serve as the price system for government decision makers. Those estimates influence the allocation of trillions of dollars of real and financial resources.

- The government's economic cost of capital includes the cost of the associated market risk because taxpayers and other government stakeholders must bear that risk.

- Governments typically understate their cost of capital because they identify it with their borrowing costs rather than with a rate of return commensurate with the risk of a project. A consequence is that the official cost estimates for many government investment and financial activities are significantly understated. However, in a few cases risk adjustment lowers estimated cost relative to official estimates.

- Using the methods of financial economics to value government projects and policies provides more comprehensive cost estimates, and also serves to highlight the underlying economics of the activities analyzed. Researchers have successfully applied those methods to a wide range of applications ranging from pension guarantees to student loans to Fannie Mae and Freddie Mac.

Despite the progress that has been made, there is a great deal of work that remains to be done in this area. On the practical side, many major government projects and policies have yet to be evaluated using a financial economics approach, for example, guarantee programs for multi-family housing and trade credit. It also is not known how much capital costs for real government investments are understated, and how much that downward bias has affected real investment decisions (in specific cases or in aggregate). Although there is an existing literature on the cost of the largest programs, those estimates and methodologies could be updated and improved upon. An impediment to this line of research is that government financial data is not routinely made public. However, researchers have successfully used the Freedom of Information Act to obtain data from the federal government, and the additional effort required increases the odds that analysis of the data will produce new insights.

There are also important conceptual issues that remain to be further explored including: 
- To what extent do market prices reflect the full cost of the catastrophic or tail risks that the government assumes, and what prices provide the best information to infer the cost to the government of those risks?

- How much do government actions--such as the large scale purchases of mortgage-backed securities by the Federal Reserve--move prices, and how should those effects be incorporated into cost estimates?

- How can the sometimes significant discrepancies between options-based and rate spread-based models be reconciled, and which approach is more relevant to government valuation?

- Are there identifiable components of market returns that should be excluded from calculations of government capital costs? For example, is illiquidity less of a cost to the government?

- Are the accounting guidelines for fair value estimates by private financial institutions the best framework to guide government cost calculations, and if not what modifications are needed?

Finally, although ex ante cost estimates are most relevant for decision-making, policymakers and the press often focus on ex post costs. For government guarantees, the median and modal ex post cost generally is lower than the estimated ex-ante cost, both because the risk premium is a non-cash expense and because the distribution of outcomes is highly left-skewed. How to effectively communicate the relevance of estimates that are systematically higher than observed cash costs remains an important challenge for researchers in this area. 


\section{Literature Cited}

Ambrose, Brent, and Arthur Warga (2002). Measuring Potential GSE Funding Advantages, Journal of Real Estate Finance and Economics 25(2/3): 129-150.

Arrow, K., and G. Debreu (1954), "Existence of an Equilibrium for a Competitive Economy, Econometrica, 22 3, pp. 265-290.

Arrow, K. and R. Lind (1970), "Uncertainty and the Evaluation of Public Investment Decisions," American Economic Review, 60, pp. 364-378.

Bazelon, C. and K. Smetters (1999), "Discounting Inside the Washington D.C. Beltway," Journal of Economic Perspectives, 13 4, pp. 213-228.

Benzoni, Luca, Pierre Collin-Dufresne, and Robert S. Goldstein. 2007. "Portfolio Choice over the Lifecycle when the Stock and Labor Markets Are Co-integrated." Journal of Finance 62(5, October) pp. 2123-2167.

Biggs, A. and C. A. Burdick, and K. Smetters (2006), "Pricing Personal Account Benefit Guarantees: A Simplified Approach," NBER Working Paper.

Blocker, Alexander W., Laurence J. Kotlikoff, and Stephen A. Ross (2008), "The True Cost of Social Security," NBER Working paper No. 14427.

Bodie, Zvi (1995), "On the Risk of Stocks in the Long Run,” Financial Analysts Journal

(2011), "Mismatch Risk, Government Guarantees, and Financial Instability: The Case of the U.S. Pension System," manuscript, Boston University

Congressional Budget Office (2001), "Federal Subsidies and the Housing GSEs," CBO Study (2003), "Evaluating and Accounting for Federal Investment in Corporate Stocks and Other Private Securities," CBO Study (2004), "Estimating the Value of Subsidies for Federal Loans and Loan Guarantees," CBO Study (2005), “The Risk Exposure of the Pension Benefit Guaranty Corporation,” CBO Study (2006), "Evaluating Benefit Guarantees in Social Security," Background Paper (2007), "Federal Financial Guarantees under the Small Business Administration's 7(a) Program," CBO Paper (2010a), CBO's Budgetary Treatment of Fannie Mae and Freddie Mac, Background Paper (2010b), "The Budgetary Impact of Fannie Mae and Freddie Mac, Letter to Honorable Barney Frank 
(2010c), “The Budgetary Impact and Subsidy Costs of the Federal Reserve's Actions During the Financial Crisis," CBO Study

(2011), "Accounting for FHA's Single-Family Insurance Program on a Fair-Value Basis," letter to the Honorable Kent Conrad, May.

(2011), "Federal Loan Guarantees for the Construction of Nuclear Power Plants, CBO Study

Debreu, G. (1959), “A Theory of Value: An Axiomatic Analysis of Economic Equilibrium,” unpublished manuscript

Diamond, Peter (1967), "The Role of the Stock Market in a General Equilibrium Model with Technological Uncertainty," American Economic Review, 57, pp. 759-776.

Elliott, Douglas (2011), Uncle Sam in Pinstripes, The Brookings Institution.

Falkenheim, M. and Pennacchi, G. (2003), "The Cost of Deposit Insurance for Privately Held Banks: A Market Comparable Approach," Journal of Financial Services Research, 24, 121-148

Fama, Eugene F., and Kenneth R. French (1992), "The Cross-Section of Expected Stock Returns," Journal of Finance 47, 427-465.

Geanakoplos J. and S. Zeldes (2010), "The Market Value of Accrued Social Security Benefits," in Measuring and Managing Federal Financial Risk, edited by D. Lucas, University of Chicago Press (2011), “The Market Value of Social Security” Columbia University working paper.

Hirshliefer, J. (1964), "Efficient Allocation of Capital in an Uncertain World," American Economic Review, 54, pp. 72-85.

Hirshleifer, J. (1966), "Investment Decisions under Uncertainty: Applications of the State Preference Approach," Quarterly Journal of Economics, 252-

Hull, John, Mirela Prediscu, and Alan White (2005), "Bond Prices, Default Probabilities, and Risk Premiums," Journal of Credit Risk, vol. 1, no. 2, pp. 53-60.

Jorgenson, D.W., W. Vickrey. T.C. Koopmans; P. A. Samuelson (1964), "Discussion," American Economic Review, 54, pp. 93-96

Kaplow, Louis (2006), "Discounting Dollars, Discounting Lives: Intergenerational Distributive Justice and Efficiency," NBER Working Paper 12239 <CHECK>

Keeley, Michael. (1990), "Deposit Insurance, Risk, and Market Power in Banking." American Economic Review 80, no. 5: 1183-200.

Kelly, Brian, Hanno Lustig, and Stijn Van Nieuwerburgh (2011), "Too-Systemic-To-Fail: What Option Markets Imply About Sector-Wide Government Guarantees," Working paper 11-12, University of Chicago Booth School 
Lachance, E.M., and O. Mitchell (2002), "Understanding Individual Account Guarantees," NBER Working Paper \#9195

Leland, Hayne E., "Corporate Debt Value, Bond Covenants, and Optimal Capital Structure", Journal of Finance, 49 (4), 1994, 1213-52.

Lintner, J. (1965), "The Valuation of Risk Assets and the Selection of Risky Investments in Stock Portfolios and Capital Budgets," Review of Economics and Statistics 47, pp. 13-37.

Lucas, Deborah (2011), “Credit Policy as Fiscal Policy,” MIT Sloan working paper.

Lucas, Deborah and Robert McDonald (2006), “An Options-Based Approach to Evaluating the Risk of Fannie Mae and Freddie Mac," Journal of Monetary Economics

Lucas, Deborah and Robert McDonald (2010), "Valuing Government Guarantees: Fannie and Freddie Revisited," in Measuring and Managing Federal Financial Risk, edited by D. Lucas, University of Chicago Press

Lucas, Deborah and Damien Moore (2007), "Guaranteed vs. Direct Lending: The Case of Student Loans," in Measuring and Managing Federal Financial Risk, edited by D. Lucas, University of Chicago Press (2009), “The Student Loan Consolidation Option,” working paper, MIT

Lucas, Deborah and Marvin Phaup (2008), "Reforming Credit Reform," Public Budgeting \& Finance (2010), "The Cost of Risk to the Government and Its Implications for Federal Budgeting," in Measuring and Managing Federal Financial Risk, edited by D. Lucas, University of Chicago Press

Lucas, Deborah and Stephen Zeldes (2006), "Valuing and Hedging Defined Benefit Pension Obligations: The Role of Stocks Revisited," Columbia University Working paper

Marcus, Alan (1987), "Corporate Pension Policy and the Value of PBGC Insurance," Chapter 3 in Issues in Pension Economics, Zvi Bodie, J. Shoven, and D. Wise, eds. University of Chicago Press.

Marcus, Alan and Israel Shaked (1984), "The Valuation of FDIC Deposit Insurance Using Option-Pricing Estimates," Journal of Money, Credit and Banking, Vol. 16, No. 4, 446-460.

Marcus, Alan J. and David M. Modest, (1986) "The Valuation of a Random Number of Put Options: An Application to Agricultural Price Supports," The Journal of Financial and Quantitative Analysis, Vol. 21, No. 1 (Mar., 1986), pp. 73-86

Merton, Robert C., (1974), "On the Pricing of Corporate Debt: The Risk Structure of Interest Rates," Journal of Finance, 29 (2), 1974, pp. 449-470.

Merton, Robert C., (1977), "An Analytic Derivation of the Cost of Loan Guarantees and Deposit Insurance: An Application of Modern Option Pricing Theory, Journal of Banking and Finance, 1(1), pp. 3-11. 
Merton, Robert C., (1978), "On the Cost of Deposit Insurance When there Are Surveillance Costs," The Journal of Business, Vol. 51, No. 3, pp. 439-452.

Moss, David A. (2004), When All Else Fails: Government as the Ultimate Risk Manager, Harvard University Press

Modigliani, F. and M. H. Miller (1958), "The Cost of Capital, Corporation Finance, and the Theory of Investment," American Economic Review, 48, pp. 261-97

Novy-Marx, Robert and Joshua Rauh (2011). "Public Pension Promises: How Big Are They and What Are They Worth?” Journal of Finance. 66(4): 1207-1245.

Pennacchi, George G., "A Reexamination of the Over- (or Under-) Pricing of Deposit Insurance," Journal of Money, Credit, and Banking, Vol. 19, (August 1987), pp. 340-60.

Pennacchi, George (1996), "Deposit Insurance, Bank Regulation, and Financial System Risks," Journal of Monetary Economics, vol. 53, no. 1, pp. 1-30.

(1999), "The Value of Guarantees on Pension Fund Returns," The Journal of Risk and Insurance, Vol. 66, No. 2 (Jun., 1999), pp. 219-237

Pennacchi, G. and C. Lewis (1994) "The Value of Pension Benefit Guaranty Corporation Insurance," Journal of Money, Credit and Banking, Vol 26, No. 3, part 2., pp. 735-753.

Daniel Pope (2008), Nuclear Implosions: The Rise and Fall of the Washington Public Power Supply System, New York: Cambridge University Press.

Sandmo, A. (1972), "Discount Rates for Public Investment Under Uncertainty," International Economic Review, 13 2, pp. 287-302.

Sandmo A. and J. Dreze (1971), "Discount Rates for Public Investment in Closed and open Economies," Economica, 38 152, pp. 395-412.

Sharpe, W.F. (1964), "Capital Asset Prices: A Theory of Market Equilibrium under Conditions of Risk," Journal of Finance, 19, pp 425-442.

Sosin, Howard B. "On the Valuation of Federal Loan Guarantees to Corporations," Journal of Finance, Vol. 35 (December 1980), pp. 1209-1221.

Stiglitz, J. and A. Weiss (1981), "Credit Rationing in Markets with Imperfect Information," American Economic Review.

Telmer, Chris, Kjetil Storesletten and Amir Yaron (1999), “The Risk Sharing Implications of Alternative Social Security Arrangements," Carnegie Rochester Conference Series on Public Policy

Veronesi, Pietro and Luigi Zingales (2009), “Paulson's Gift," University of Chicago Working Paper

Williamson, Stephen D. (1994), “Do Informational Frictions Justify Federal Credit Programs?” Journal of Money, Credit and Banking, Vol. 26, No. 3, Part 2, pp. 523-544 


\section{Appendix}

To see the equivalence between a debt guarantee and a put option on the assets of a firm, consider an insured firm and otherwise identical uninsured firm (denoted with superscripts " $I$ " and " $U$ " respectively; quantities without superscripts are the same for both). ${ }^{16}$ Suppose that at time 0 each promises the same debt payment at maturity $T, D_{0}(T)$, and have the same initial value of operating assets, $A_{0}(0)$. The only source of uncertainty is the value of operating assets, which evolve identically but stochastically over time. At time 0 , the equity value of the going concern is the present value of the expected payoff to equity holders. Let $\mathrm{E}_{0}[$.] denote the expectation conditional on time 0 information under the risk neutral measure. Because both firms have the same physical assets and the same promised debt repayment, the market value of equity of both firms is: $E_{0}(0)=e^{-r T} \mathrm{E}_{0}\left[\max \left(0, A_{0}(T)-D_{0}(T)\right)\right]$ where $r$ is the riskfree rate. Between times 0 and $T$, the equity values remain the same: both claims are a call option on the same underlying assets, with identical strike price and maturity.

Unlike for equity, the present value of the debt of the two firms prior to maturity is not equal. At any time $t \leq T$, the value of insured debt is the present value of the certain payment: $D_{0}^{I}(t)=e^{-r(T-t)} D_{0}(T)$. The realized payment on uninsured debt will be the promised amount, $D_{0}(T)$, or the asset value at time $T$, $A_{0}(T)$, whichever is less. Hence the value of uninsured debt is the present value of the expected payment to debt holders: $D_{0}^{U}(t)=e^{-r(T-t)} \mathrm{E}_{t}\left[\min \left(A_{0}(T), D_{0}(T)\right)\right]$.

The value of the $T$-period guarantee made at time $0, G_{0}(0)$ is the difference between the initial value of the insured and uninsured debt:

$$
G_{0}(0)=e^{-r T} D_{0}(T)-e^{-r T} \mathrm{E}_{0}\left[\min \left(A_{0}(T), D_{0}(T)\right)\right]=e^{-r T} \mathrm{E}_{0}\left[\max \left(D_{0}(T)-A_{0}(T), 0\right)\right]
$$

The expression on the right-hand side of (1) is the value of a put option on the operating assets of the firm, where the strike price is the promised payment on debt. When assets are lognormally distributed, the value can be computed using the standard Black Scholes formula for a put option.

The value of the guarantee generally accrues to equity holders. If the government charges fees for the guarantee, then the present value of the fees will partially or fully offset the value of the guarantee to equity holders.

\footnotetext{
${ }^{16}$ The example is taken from Lucas \& McDonald (2010).
} 